\title{
成人期先天性心疾患の病理学的研究
}

\section{Pathology of Congenital Heart Disease in Adulthood}

\author{
順天堂大学医学部心臓血管病理学研究室 \\ 岡田 了三・河野 靖子
}

Research Laboratory for Cardiovascular Pathology, Juntendo University School of Medicine. Ryozo Okada, Yasuko Kawano

〔はじめに〕

先天性心疾患患者の予後は原疾患の重症度によっ て決まることが多いが，従来から成人期に屡々みら れる心房中隔欠損症 (ASD)，心室中隔欠損症 (VSD)， Fallot 四徵症 (TOF)について, 治療法の進歩によっ て現状ではどの程度予後が改善されているか?およ び，それらの疾患の予後を規定する因子は何である か? 病理形態学的に検討した.

I . 日本病理剖検輯報からみた ASD, VSD, TOF の予後 1990 年 1 月 1 日より同年 12 月 31 日までの本 邦全域に互る病理解剖例が登録されている日本病理 剖検輯報第 33 輯(1991) ${ }^{1)}$ に記載されている ASD, VSD, TOF の総数は表 1 に示すように，各 58， 35, 57 例である。これは同年の総病理解剖 38,526 例中 それぞれ $0.15 \% ， 0.09 \% ， 0.15 \%$ に当たる。，その 平均年齢は ASD 41.0 歳, VSD 9.4 歳, TOF 11.0 歳 である。手術例は ASD で 10/58, 17\%;VSD で8/35, $23 \%$; TOF で $31 / 57,54 \%$ で，手術 $(+),(-)$ 群の 平均年齢はASD で $(+) 47.3$ 歳, (一) 39.7 歳; VSD で $(+) 16.8$ 歳, (-) 7.3歳; TOF で $(+) 5.1$ 歳, (-) 18.1歳である，ASD，VSDでは手術 $(+)$ 例の方が (一)例をそれぞれ 7.6 年, 9.5 年上迴り，手術によ る延命効果が評価できるが, TOF では逆に手術 $(-)$ 例が13年上廻る予後を示す.

表 1 剖検輯報 (1990 年剖検例) 中の ASD, VSD, TOF 統計

\begin{tabular}{|c|c|c|c|c|c|c|}
\hline & \multicolumn{2}{|c|}{$\begin{array}{c}\text { 心房中隔 } \\
\text { 欠損症 }\end{array}$} & \multicolumn{2}{|c|}{$\begin{array}{c}\text { 心室中隔 } \\
\text { 欠損症 }\end{array}$} & \multicolumn{2}{|c|}{$\begin{array}{l}\text { ファロー } \\
\text { 四徵症 }\end{array}$} \\
\hline $\begin{array}{c}\text { 症例数 } \\
\text { 平均年齢（歳） }\end{array}$ & \multicolumn{2}{|c|}{$\begin{array}{c}58 \\
41.0\end{array}$} & \multicolumn{2}{|c|}{$\begin{array}{l}35 \\
9.4\end{array}$} & \multicolumn{2}{|c|}{$\begin{array}{c}57 \\
11.0\end{array}$} \\
\hline 手術 & $(+)$ & $(-)$ & $(+)$ & $(-)$ & $(+)$ & $(-)$ \\
\hline $\begin{array}{c}\text { 症例数 } \\
\text { 平均年歯佱) } \\
\end{array}$ & $\begin{array}{c}10 \\
47.3 \\
\end{array}$ & $\begin{array}{c}48 \\
39.7\end{array}$ & $\begin{array}{c}8 \\
16.8 \\
\end{array}$ & $\begin{array}{l}27 \\
7.3 \\
\end{array}$ & $\begin{array}{l}31 \\
5.1 \\
\end{array}$ & $\begin{array}{c}26 \\
18.1 \\
\end{array}$ \\
\hline \multicolumn{7}{|l|}{ 合併症 } \\
\hline $\begin{array}{c}\text { 肺高血圧症 } \\
\text { 感染性 } \\
\text { 心内膜炎 }\end{array}$ & $\begin{array}{r}18 \\
1\end{array}$ & $\begin{array}{l}31 \%) \\
2 \%)\end{array}$ & $\begin{array}{r}3( \\
2(\end{array}$ & $\begin{array}{l}37 \%) \\
6 \%)\end{array}$ & & 0 \\
\hline
\end{tabular}

この手術 (一) 例を1972年発表の Campbell による 剖検例からみた ASD, VSD, TOF の自然歴 ${ }^{2)}$; ASD 38歳, VSD (大型) 22歳, TOF 12歳と比較すると, 輯報例で ASD が+2 歳, VSD でー15歳, TOF で+ 4 歳という結果になる。 ASD, TOFでは輯報例の
予後は僅かによくなっているが, VSD では手術 $(+)$ 例ですらー 5 歳と，より短命である。この VSDに おける相違は如何なる理由によるものであろうか？ 本邦における新生児期の先天性心疾患剖検例中の VSD 頻度は安藤 ${ }^{3)}$ によれば $3.7 \%$ であり TOF の $2.4 \%$ を廻っている。この出現率は輯報総剖検例 中の TOF $0.15 \%$ から逆算すれば，VSD で $0.23 \%$ に 当ることになり，今回の $0.09 \%$ という出現率の少 くとも 2.6 倍存在することになる。この差は生後に 発生するVSDの自然閉鎖による減少によって生じ る可能性が高い。このデータから逆算すると新生坚 期のVSDの $61 \%$ は自然閉鎖するという計算になる。 この数值は，著者の経験による無選択的な成人の剖 検例中, VSD 自然閉鎖所見の発見率が，1/400す なわち $0.25 \%$ であることから，ほぼ妥当な数字と 言える。，その点を考慮するとCampbell 論文の大型 VSDの予後に比して本邦のVSD で手術の有無にか かわらず短命に終る例が存在することの説明は難し い. しかし全身奇形の一部としての VSD では予後 は心外奇形の重症度で決まる場合もあることなどか ら本邦人とユーラシア人種間での合併症の出現率の 相違などを想定する必要があろう。その点を検討す るため輯報に記載されている合併症を表 1 下段に示 す.肺高血圧症は ASD で $31 \%$, VSD で $37 \%$ であり， 手術不能の,Eisenmenger 症候群の予後の悪さが, 輯 報中の VSD が短命であることの一因を成している と推定できる。合併症としての感染性心内膜炎(IE) が死因につながる率は現在では低く輯報例では ASD 2\%，VSD 6\%である。

図 1 に ASD, VSD，TOF 輯報例の年齢分布を男 女別に示寸. 14 歳以下，15 59 歳，60 歳以上に 3 区分するとASD ではそれぞれ $33 \%, 31 \%, 36 \%$; VSD では $83 \% ， 14 \% ， 3 \%$; TOF では $81 \%, 12 \%$, $7 \%$ となり，ASD で高齢者が相対的に多い事実が わかる。 その成績は Campbell の 1970 年の報告 ${ }^{4)}$ と ほぼ同じである。また肺高血圧症の合併は ASD で は加齢とともに増加し, VSD は年齢と無関係にみ られる傾向がある。この点では，VSD の大部分は 正常人並の良い自然歴をもち, 剖検に顔を出す機会 が少ないとみて間違いないが，意外に短命に終る少 数例もあることが注目される. TOF では 30 歳以上 

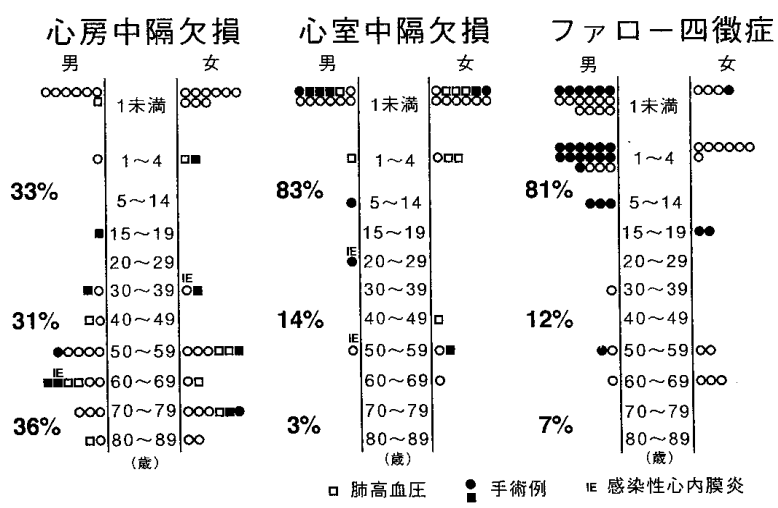

図 1 剖検輯報 (1990 年剖検例) 中の ASD, VSD, TOF の年 齢分布

の 9 例中, 手術例は 1 例のみで, 現状では手術によ る延命効果に限界があることが想像される。

II. 成人期 ASD, VSD, TOF の症例提示

図 2 例. 58 歳，男。心不全死に終った中等大の 卵円窩型 ASD 例である。心重量は $770 \mathrm{~g} ， \mathrm{~A}$ のよう に右房, 右室は著しく拡張し, 三尖弁尖の不規則な 線維性肥厚 ${ }^{5)}$ とともに弁口の拡大による三尖弁閉鎖 不全が合併している．Ｂに示す心室中間部横断面で は右室容積は左室の数倍に達するが, 壁厚は正常範 囲内にある。右室心筋はCにみられる線維症と, 拡張型心筋症を思わせる変性所見を呈する．長年に 瓦る右室容積負荷が心筋の代償不全を招いたための 死亡とみなされる。

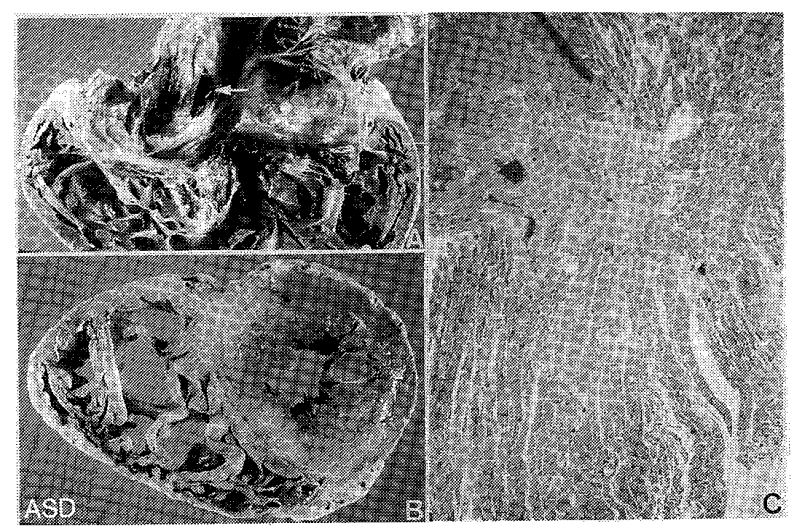

図 2 卵円䆟型 ASD. 58 歳, 男.

A. 右側内面，中等大の卵円窝内欠損 (矢印)，右 房・右室の著しい拡張と心内膜の斑状肥厚. 三尖弁 口のつよい拡大と弁尖の不規則覀びまん性の線維性 肥厚. B. 心室中間部の横断面. 下方が前面. 左方が 右室. 右室の著明な拡張とほぼ正常の壁厚. 心室中 隔より右室にかけて線状・斑状の線維症の散在. C. 右室心筋. $20 \times$, アザン染色. クモ状の不規則な置 換性および間質線維症とその周辺の心筋細胞配列の 乱れ. 心筋細胞の肥大, 大小不同, 変性. 間質の開大.

図 3 例. 74 歳，男. 不整脈死を遂げた中等大の 卵円窩型 ASD 例である。心重量は $390 \mathrm{~g} ， \mathrm{~A}$ に示す
ように右房・右室の中等度の拡張と心内膜のびまん

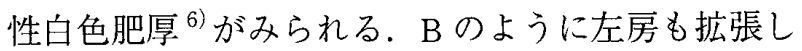
て, 心内膜肥厚が目立つ. 僧帽弁尖は逸脱を伴う特 有の限局性線維性肥厚 ${ }^{7)}$ を呈する。右室壁の組織像 はCのように心内膜の線維弾性症, 心筋内血管周 囲線維症とともに心内膜下ょり中層に及ぶ脂肪組織 の浸潤を示す．右室心内膜のびまん性肥厚は容積負 荷の増大によって生じるが, 進行すると, 成人期に 拡張制限とともに拘束型血行力学的異常の一因とも なりうる。また僧帽弁逸脱の合併は逆流による左心 不全の原因となる可能性がある.
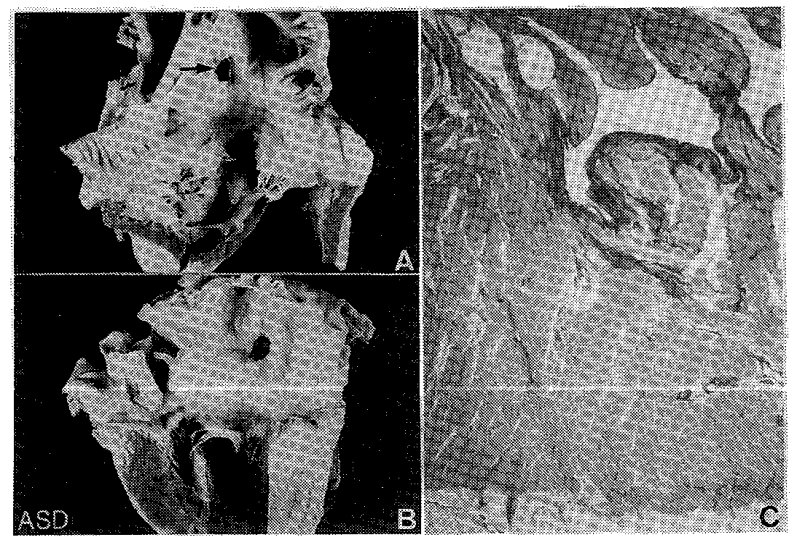

図 3 卵円窩型 ASD.74 歳, 男.

A. 右側内面. 中等大の卵円窝内欠損 (矢印). 右 房 - 右室の中等度拡張と心内膜の白色びまん性肥厚. 三尖弁口の中等度拡大と弁尖の不規則亜びまん性の 線維性肥厚. B. 左側内面. 左房の中等度の拡張と心 内膜の白色びまん性肥厚. 正常大の僧帽弁口と弁尖 の後交連を中心とした線維性肥厚 (ASD plaque) と逸 脱. C. 右室心筋. $10 \times$, エラスチカ・ワンギーソン 染色. 心内膜の線維弾性症. 心筋内血管周囲線維症 と広沉な間質脂肪浸潤.

図 4 例. 36 歳, 男. 心不全の治療中急死を遂げ た二大血管直下の大型 VSD 兼卵円窩型 ASD 例であ る。心重量は $980 \mathrm{~g} ， \mathrm{~A}$ に示す右室は著しい拡張と 比較的軽度の肥厚, B に示す左室は著明な拡張と, ほほ正常の壁厚を呈する．雨室の心内膜は中等度び まん性に肥厚する。右室心筋はCのように間質の 水腫性開大と線維症，心筋細胞の肥大・巣状脱落に 加えて, 矢印に示す心内膜下の Purkinje 細胞群の 急性変性・壊死を示し，それが心室性不整脈源であ ることが示唆されるＶVSDの存在による雨室負荷 の増大が，代償性肥大の限度を超えて心筋不全を生 じたことが推定できる。

図 5 例. 70 歳，女 ${ }^{7)}$. VSD に定型的な収縮期雑 音あり, 高血圧の治療を受けていた。発熱一ヶ月後, 全身衰弱で死亡した。心臟は $420 て ゙ ，$ 右室流入路は 正常容積と正常壁厚, 流出路は拡張, 左室は正常容 積で肥厚を呈する，三尖弁の交連尖の裏側に位置す るVSD はA大矢印のように弁尖・腱索の癒合に 


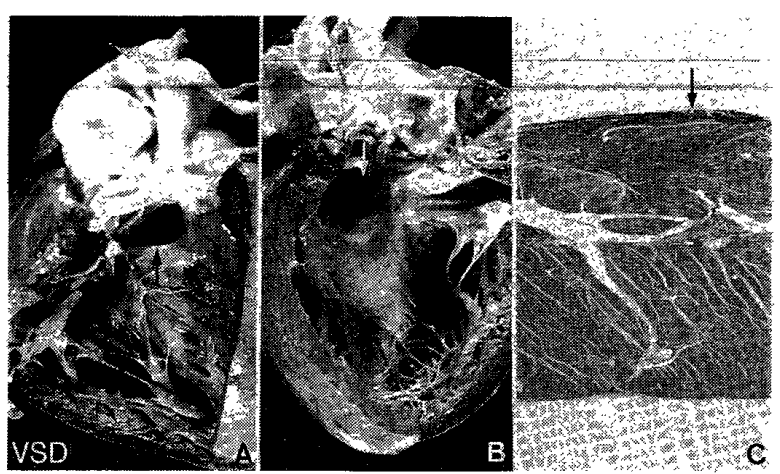

図 4 大血管下型VSD.36 歳, 男。

A. 右室流出路. 肺動脈弁下大型 VSD (矢印)。右 室の高度な拡張と軽度の肥厚. 斑状の心内膜肥厚. B. 左室流出路. 大動脈弁下膜性部より前方の VSD（矢 印)．左室の著しい拡張とほぼ正常の壁厚．心内膜の 斑状肥厚と大動脈弁逆流による半月状の心内膜ポ ケット形成. C. 右室心筋. $10 \times$, アザン染色. 間質 の水腫状開大と線維症．心内膜下 Purkinje 細胞の急 性变性・壊死 (矢印).

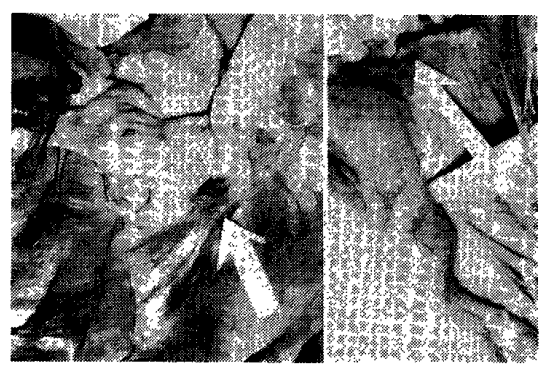

図 5 感染性心内膜炎を合併した VSD.70 歳，女，

A. 右側内面. 自然閉鎖機転の進行した三尖弁下膜 性部小型 VSD (大矢印)。短絡ジェット血流の当たる 三尖弁後尖上の増殖物 (小矢印)，B. 左室流出路. 膜 性部横長の小 VSD (大矢印).

よって，帽針頭大の大きさに狭められており，小孔 より噴射される左・右短絡ジェット血流が衝突する 後尖上に小矢印で示す増殖物がみられ, 感染性心内 膜炎の合併が診断できる。VSDの左側は B 図のよ うに大動脈弁下, 膜性部に横長の小型 VSD として 開存し，その上下縁には線維組織による土手状の構 造物がみられる、VSDの自然閉鎖過程が進行して, 短絡ジェット血流の流速が強まると，その衝突によ る心内膜の損傷が流血中の微生物の付着を誘発して 感染性心内膜炎を発症すると理解できる。

図 6 例. 46 歳, 男. 高血圧を合併し, 労作時息 切れあり，嘔吐・下痢の後突然意識消失して死しし た。心重量は $480 \mathrm{~g}, \mathrm{~A}$ 図のように右室は著しい肥 厚を示し, 流出路は黒矢印の部位で心内膜の帯状肥 厚を伴うロト部狭窄と弁性狭窄をもち, ゾンデを通 したVSD は大動脈下に位置するTOFである，心室

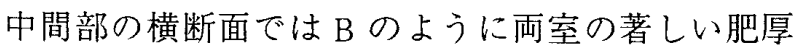
と, それを上廻る心室中隔肥厚がみられ，肥大型心 筋症類似の外観を呈する。肥厚した心筋中には雲
状・線状の多数の線維症が散在し，肥大した心筋細 胞の配列の乱れもみられる。

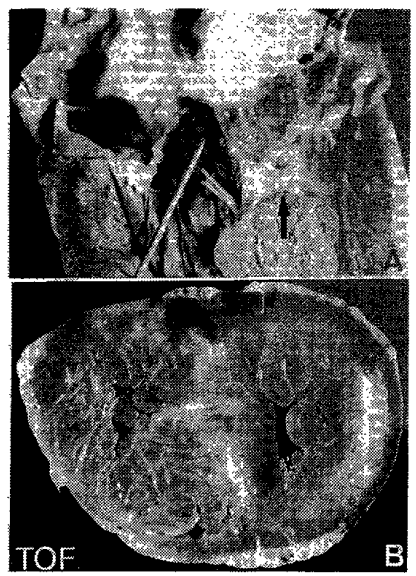

図 6 TOF. 46 歳, 男.

A. 右側内面. 中等度の右房拡張と高度の右室肥厚。 大動脈弁下 VSD (ゾンデ). 右室流出路 (矢印) と肺動 脈弁狭窄. B. 心室中間部横断面. 下方が前面, 左方 が右室. 心室中隔の非対称性肥厚と右室の求心性肥厚. 不規則線状・斑状・渦巻き状の心筋線維症

III. 形態計測による ASD, VSD, TOF の心室肥大の特 徵

心室には容積負荷・圧負荷により異なる特徵を示 す拡張・肥厚が発生するが，それが限度を越えると 心不全を発症するとみなされる。そこで，ホルマリ ン固定心を用いて，右室 $(\mathrm{RV})$ を底辺を上にした逆 円錐二個, 左室 $(\mathrm{LV})$ を同一個とみなして，その容 積 $\mathrm{V}_{\mathrm{RV}}, \mathrm{V}_{\mathrm{LV}}$ を右室流入路周囲長 (中間部) $\mathrm{P}_{\mathrm{RV}}$, 流出路周囲長 (中間部) $\mathrm{P}_{\mathrm{RV}}$, 三尖弁 - 心尖長 $\mathrm{TA}$, 心尖・肺動脈弁口長 PA, 左室周囲長 (中間部) $\mathrm{P}_{\mathrm{LV}}$, 僧赗弁 - 心尖長 MA, 心尖・大動脈弁口長 AA を用 いて次のように算定した ${ }^{8)}$.

$$
\begin{gathered}
\mathrm{V}_{\mathrm{RV}}=1 / 3 \cdot \mathrm{TA}\left(\mathrm{P}_{\mathrm{RVi}} / 2 \pi\right)^{2}+ \\
1 / 3 \cdot \mathrm{PA}\left(\mathrm{P}_{\mathrm{RVo}} / 2 \pi\right)^{2} \pi \\
\mathrm{V}_{\mathrm{LV}}=1 / 3 \cdot(\mathrm{MA}+\mathrm{AA}) / 2\left(\mathrm{P}_{\mathrm{LV}} / 2 \pi\right)^{2} \pi
\end{gathered}
$$

また心室壁厚は右室流入路・左室では乳頭筋を避 けた側壁中間部で肉柱を除いた緻密層の厚さ，右室 流出路では肺動脈弁下での緻密層の厚さとして計測 した。

図 7 は ASD 右室の計測値を示す. 左側は右室容 積で, 年齢・性を一致させた正常対照例と比較する と, 30 歳台後半までは加齢とともに拡張が進行し, 正常值の約 4 倍で頭打ちとなり, 以後は横這いとな る. 中央の流入路の壁厚はバラッキが大きく, 40 歳以後で大部分は正常の 2 倍に達する. 右側の流出 路壁厚は更にバラッキが大きく厚い例と薄い例が混 在する. ASD 左室容積は 30 歳台後半以後で正常の 2 倍に達する例とほぼ正常の例がそれぞれ半数づつ を占める。

VSD では各計測值ともにバラッキが大で左室容 


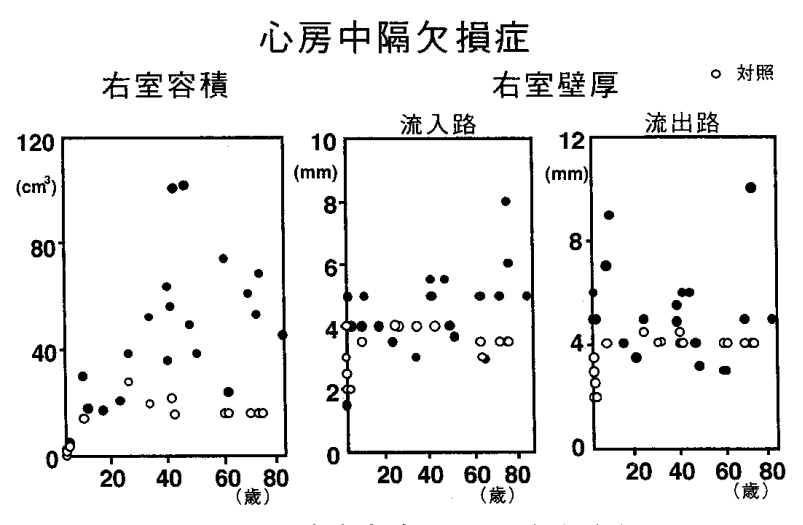

図 7 ASD の右室容積と壁厚の加齝変化

積の大きい傾向および肺高血圧例での右室肥大傾向 はあるが，加齢による頭打ち現象は明らかでない.

TOF では右室容積はほほ正常で壁厚のみ増大す る圧負荷型肥大の特徵が明らかである。図 8 は TOF の右室壁厚の計測值で, 左に流入路, 右に流 出路の厚さを示す．流入路では正常の 3 倍 $1.0 \mathrm{~cm}$ に達し, 以後横這いとなるが, 流出路では 20 歳ま で増加傾向が続く.

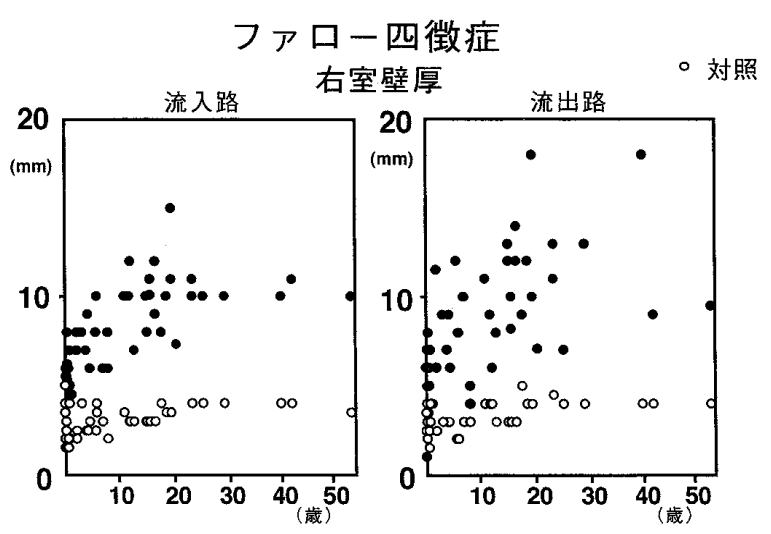

図 8 TOF 右室壁厚の加齢変化

以上の事実から ASD では右室の拡張は 40 歳まで, TOF では右室肥厚は 10 歳までで頭打ちとなること が，それ以後の心機能の潜在性代償不全の発生に重 要な役割りを演じていると考えられる ${ }^{9)}$. VSDでは, 血行力学的異常による形態学的変化は一様でなく, 成人期の問題は肺血圧症をはじめ，個々の症例に よって異なることが特徴的と言える。
[まとめ]

成人期先天性心疾患の形態学的特徴から次の問題 が提起される。

ASD では中年過ぎの右心不全および一部の左心 不全の合併, VSD では肺高血圧症と感染性心内膜炎, TOF では少年期以後の右室壁厚増加に付随する合 併症である．今後は手術例の予後および自然歴の改 善のためにこれらの問題の解決を求めて一層の努力 が必要であろう。

[文 献]

1）日本病理剖検輯報, 第 33 輯. (平成 2 年度剖 検例収載) 日本病理学会編. pp. 1-1559，1992. 日本病理剖検輯報刊行会, 東京.

2) Campbell $\mathrm{M}$ : Natural history of cyanotic malformations and comparison of all common cardiac malformations. Brit Heart J, $1972 ; \mathbf{3 4}$ : 3-8.

3) 安藤正彦: 最新内科学大系. 第 38 巻. 先天 性心疾患. I. 発生頻度, 分類, 成因. 杉本恒明, 矢畸義雄, 泰江弘文編. pp. 3-25，1991. 中山 書店, 東京.

4) Campbell $\mathrm{M}:$ Natural history of atrial septal defect. Brit Heart J, 1970;32:820-826.

5) Okada R, Glagov S, Lev M:Relation of shunt flow and right ventricular pressure to heart valve structure in atrial septal defect. Amer Heart J, $1969 ; 78: 781-795$.

6) Okada R, Glagov S, Lev M:Different effects of increased volume and increased pressure on endocardial structure in hearts with atrial septal defect. Amer Heart J, 1968 ; 75: 474-486.

7) Nakanishi A, Morii T, Okada R, Inoue S,Shimada $\mathrm{H}$ : A case report of ventricular septal defect in the aged - Inter relation between its closing process and subacute bacterial endocarditis. Jpm Heart J, 1968; 9:219-223.

8）岡田了三: 心臓の形態学 (11).メデカルエレ クトロタイムス, $1970 ; 12: 93-101$.

9）早河秀治, 門間和夫, 高尾篤良: 肺高血圧症 を合併した心房中隔欠損症の自然歴: 16 歳以上 の内科的治療例における検討. J Cardiol, 1994 ; 24 : 107-113. 